\title{
STEM CELL TREATMENT FOR AGE-RELATED NEURODEGENERATIVE DISEASES
}

\section{AUTHORS}

Nurkovic J. ${ }^{1}$, Bisevac B. ${ }^{2}$, Mustafic F. ${ }^{3}$, Hajrovic S. ${ }^{4}$, Regic E. ${ }^{4}$, Nurkovic S. ${ }^{5}$, Kurtagic I. ${ }^{5}$, Dolicanin Z. ${ }^{1}$

${ }^{1}$ Department of Biomedical Sciences, State University of Novi Pazar, Serbia

${ }^{2}$ Faculty of Medical Sciences, University of Priština, Kosovska Mitrovica, Serbia

${ }^{3}$ Medical School of Novi Pazar, Serbia

${ }^{4}$ General Hospital Novi Pazar, Serbia

${ }^{5}$ School of Medicine, University of Belgrade, Serbia

CORRESPONDENT

JASMIN NURKOVIĆ

Department of Biomedical Sciences, State University of Novi Pazar, Serbia

jnurkovic@gmail.com

\section{SUMMARY}

The belief in the inability of neurogenesis, that is the inability to create new neurons after embryonic and early postnatal development of the central nervous system, was rejected in the mid-nineties, when the existence of neurogenesis in restricted areas of CNS adult mammals, including humans, was discovered.Transplantation of stem cells or their derivatives into respective tissues or organs is considered as one of the most promising remedies for many incurable diseases. In this review, we summarized current knowledge and present and future perspectives andchallenges regarding stem cells treatment for Parkinson's and Alzheimer's disease, as the most common age-related neurodegenerative diseases.

Key words: stem cells, Parkinson's disease, Alzheimer's disease

\section{INTRODUCTION}

Stem cells are self-renewing, unspecialized cells capable of differentiating into any specialized cell type in the human body [1].Stem cells are important for embryonic development and organogenesis, but also for tissue homeostasis and regeneration in the post-natal and adult stages of life [2].Stem cells have three important characteristics: self-renewal, clonality and differentiation potential into multiple cellular lineages [3-5].

According to the source, stem cells can be classified into embryonic (ESCs), fetal (FSCs), and adult stem cells (ASCs) [6]. ESCs are the most undifferentiated cells found in early development,first derived from the inner cell mass of the blastocyst.After fertilization and first two divisions, formed cells are totipotent, and they are capable of differentiating into three germ layer cells and extraembryonic tissues [7]. Recently, Takahashi and Yamanaka generated pluripotent cells by reprogramming somatic cells through overexpression of Oct4, Sox2, Klf4, and c-Myc. These cells are called induced pluripotent stem cells (iPSCs) and share similar characteristics with ESCs [8]. FSCs are undifferentiated cells found in the organs of fetuses, such as neural crest, hematopoietic system and pancreatic islet. These cells have a low potential compared to theESCs, but greater potential compared to the ASCs [9].Although the activity of stem cells in many tissues and organs is proven, the exact localization of ASCs is still not known because of current lack of well-defined tissue-specific markers. It is assumed that adult stem cells are in mobile niches and thus provides tissue homeostasis [10]. Hematopoietic stem cells (HSCs) and mesenchymal stem cells (MSCs) are the most recognized ASCs. ASCs are adherent to cell culture dishes and are characterized by specific surface cell markers. These cells can differentiate into mesoderm-derived tissue, such as adipose tissue, bone, cartilage, and muscle. Recently, ASCs were differentiated into neuronal tissue which derive from the ectoderm. This is an example of transdifferentiation, i.e. when a cell from one germ layer (mesoderm) differentiates into neuronal tissue (ectoderm) [11-13].

In addition to ability to differentiation, stem cells can modulate the immune response and thereby a therapeutic effect against many diseases, including neurological disorders. With the advancement of stem cell technologies and the ability to generate different types of neuronal and glial cells from stem cells, there is hope for stem cell therapeutics as novel treatments for neurological diseases [14].

\section{NEUROGENESIS}

There are several major challenges in the treatment of incurable neurological disease. The nervous system remains till today the least understood system of all, even with most research concentrating on it for the past few decades. Another factor is that neuronal cells are one of the very few body cells that remain almost postmitotic. A third reason is the scarcity and restriction of the endogenous pool of neuronal stem cells [15]. Neurogenesis occurs in a specialized microenvironment estab- 
lished by both the neurogenic and non-neurogenic cells within the neurogenic area, and from cells and compartments in direct contact with the niche [16]. Carriers of neurogenesis in the adult CNS are stem cells - neural progenitor cells (NPC), which are capable of self-renewal, i.e. creating identical daughter cells, and differentiation of cells towards a neuronal or glial type [1719]. The number of these cells is relatively small and limited to few regions of adult CNS, where they reside in "stem cell niches" - the hippocampus, and subgranular zone[20], the dentate gyrus and the subventricular zone of the lateral chamber[21]. However, in the past decade researchers have showed that neurogenesis and gliogenesis are widely spread in the adult brain, particularly after injury [22, 23]. In niches ruled optimal conditions for self-renewal of NPC. Adult neurogenesis is not static, and its rate may fluctuate in response to environmental change, even subtle microenvironmental alterations. Stressors modify this microenvironment, whereas NPCs are not spared by the systemic stress responses driving adaptation. Hypoxia, inflammation, metabolic or psychological stressors have been shown to provoke the altered NPCs "behavior" as a reaction to the modified environment [24]. The amount of stem cells, as well as the speed of neurogenesis in the adult CNS are not sufficient for the regeneration and repair of defects that exist in neurological diseases, although shown to stimulate neurogenesis of brain tissue damage, as well as the particular hormones and neurotransmitters, but also that there is a circulating population of stem cells in the blood, that could perform supplementation of NPC of adult CNS[25]. Possible therapeutic exogenous sources of stem cells are ESCs, FSCs, ASCs and iPSCs [26-28].

\section{PARKINSON'S DISEASE}

Parkinson's disease (PD) is most frequently neurodegenerative disorder which affects elderly individuals. During the course of the pathogenesis of PD there is a decrease of neurotransmitters dopamine in the basal ganglia: pars compacta substantia nigra with consequent denervation of the striatum, which results bradykinesia, rigidity, tremor and postural instability [29]. Existing therapies for PD only treat symptoms but do not address the underlying cause. Currently, the PD is treated with pharmacological substances and/or neurosurgical approach. The major treatment for PD is dopamine precursor, L-DOPA, with carbidopa to prevent systemic effects of the drug. Besides this cure, other drugs can also be used for example dopaminergic agonists (e.g., pramipexole and ropinirole) and drugs that slow the catabolism of DA in the brain (e.g., entacapone) [30]. Additionally, Olanow et al. showed that drug rasagiline, a selective irreversible inhibitor of monoamine oxidase-type $B$, can slow or delay disease progress and may offer disease modification [31]. Taken together, these drugs are considered the gold standard of pharmacological treatment to restore dopaminergic function, although, with time, patients no longer respond to these treatments. In patients who are nonresponsive to pharmacological interventions, neurosurgical approaches and enzymatic enhancement therapy are considered. Unfortunately, a reliable long-term treatment to halt the progression of the disease and restore motor and cognitive function remains elusive [30, 31].
Progress in the field of stem cells "opens the door" to potential use of these cells in the treatment of PD [32]. The results of the first, small clinical trials with intrastriatal transplantation of fetal dopaminergic neurons have shown that the transplanted neurons to survive and the dopamine released and reinnervation of the striatum [33-35]. However, there were some disappointing results in terms of frequent untoward side effects, such as dystonia and dyskinesia [35]. Soon initiated a series of clinical studies [34-36]. Kordower et al. treated 40 patients with a severe form of PD (at 20 he performed the implantation of fetal mesencephalic tissue in the putamen bilaterally, and in the other 20 "false neurosurgery without implantation")[34]. The results were unexpectedly modest. In fact, some improvement has been achieved in patients younger than 60 years, but there has been development of dystonia and dyskinesia in $15 \%$ of transplant patients after one year.At the same time, survival and preservation of function of the transplanted stem cells rich in dopamine was confirmed [34, 35]. In another placebo - controlled study led by Olanow, a clinical improvement was achieved on the border of statistical significance, $56 \%$ of patients have developed dyskinesia [36]. For graft-induced dyskinesia was found that is not the result of excessive release of dopamine from the graft, but the possible consequences of the uneven and partial reinnervation of the striatum[37]. Thus, the better the selection of patients or the selection of those with less advanced disease, would provide a better clinical effect after transplantation. The use of stem cells from bone marrow that have been amplified in vitro and differentiation to the dopaminergic neurons, would significantly improve the transplantation in PD, because of the ethical constraints which carries the application of fetal stem cells and the fact that a larger number of fetuses for transplantation one[35]. Also, it is necessary to locate the transplant prior to the degeneration of dopaminergic neurons by using $18 \mathrm{~F}$ - dopa uptake using positron emission tomography (PET), and then perform multiple target implantations of stem cells in these parts, which would result in better clinical recovery and lack of dyskinesia [36]. However, owing to limited tissue availability and other issues surrounding cell therapy, the use of fetal tissue is unlikely to become a routine treatment for PD. Currently, the major focus in this area is on developing pluripotent/reprogrammed cell-based strategies.

Recently, encouraging results have been published application line derived glial cell neurotrophic factor, GDNF, in the form of direct infusion of the putamen of patients with PD during one year[38]. This growth factorexpressing stem cells transplanted into the experimental model of PD.It has been shown that it exhibits a powerful neuroprotective action, affecting the recovery of dysfunctional dopaminergic neurons, which opens the possibility of its application in combination with the transplantation of stem cells in a PD [38].

However some questions remain unanswered, such as: the low survival rate of dopaminergic neurons in grafts, difficulty in integrating transplanted cells into the host brain's circuitry, defining the number of dopaminergic neurons needed for a transplant, site of injection, and graft-induced dyskinesia. Solving these issues will require properly controlled animal and human studies using a well characterized cell product made with defined protocols and reagents. 


\section{ALZHEIMER'S DISEASE}

Alzheimer's disease (AD) is neurological disease, which is characterized by progressive deterioration of neurons and neural synapses in different parts of the brain, such as cortex, hippocampus, amygdale and nucleus basalis of Meynert. Typically, several years passesbetween the initial onset of symptoms and eventual death. Increased extracellular amyloid plaques and intracellular neurofibrillary tangles in the brain seem to play essential role in pathogenesis of $A D$. Particularly significant is the deficiency of cholinergic neurons in the nucleus basalis of Meynert given that this region is responsible for cholinergic innervations of the cortex and hippocampus, and just a lack of acetylcholine is considered crucial for the development and manifestation of $A D$ [39]. Clinical characteristics are progressive loss of memory and other cognitive functions with dementia and progressive depletion of daily-living activities as consequence. Available therapy is based on enhancing cholinergic function in the brain by using an inhibitor of acetyl cholinesterase, which has a limited effect, although cognitive improvement and psychiatric repairment are possible. In this regard, cell-replacement therapies, such as ESC, FSC, ASC or iPSC derived neural cells, hold potential for treating $A D$ patients who may be beyond the help of pharmacological therapies [40, 41].

$A D$ models in rats that received NPC exhibited an increased hippocampal volume and synaptic density, which improved cognitive function, learning and memory [4245]. Thus, the therapeutic target in the treatment of $A D$ could be a stimulation of neurogenesis in the hippocampus. Neurogenesis stimulates learning, social contacts, physical activity, high levels of estrogen, diet, corticosteroids, stress, inflammation and subordinate, inferior position of the individual as an inhibitor. Interestingly, neurogenesis is reduced in depression, and all known anti-depressants, even electroconvulsive therapy, stimulate neurogenesis according to the data obtained in studies [46-49]. Intraventricular transplantation of human NPC overexpressing choline acetyltransferase sufficiently restored learning and memory ability of $A D$ rats [44]. In addition, a recent study demonstrated that human MSCs can enhance autophagy in amyloid B-treated neurons and mice, thus promoting amyloid $B$ clearance and increasing neuronal survival against amyloid $B$ toxicity [50]. Transplantation of human adipose tissue-derived MSCs into the brains of aged mice enhance the levels of acetyltransferase, thereby significantly improve the cognitive ability and locomotor functions of the mice [51]. Furthermore, in patients with $A D$ reduced number of circulating HSCs (CD34+ cells) were found [52]. Bearing in mind the potential of hematopoietic stem cells to differentiate to neurons, this finding could speak in favor of the failure of these particular cells under conditions of heightened need for repairing the damaged parts with $A D$ [53]. In this way, even systemic application of hematopoietic stem cells or mesenchymal stem cells would have justification in treating $A D$.

Grafted NPCs can also be significantly influenced in their migration and differentiation by the microenvironment in recipient brains. Nerve growth factors (NGF) are thought to promote survival and differentiation of transplanted NPCs. Accordingly, it is shown that the use of NGF, which prevents depletion of cholinergic neurons, have a neuroprotective effect and leads to the improvement of memory in an animal model of AD [54, 55].

New studies show potential of medial ganglionic eminence (MGE) cells. MGE is an embryonal structure of ventral telencephalon which can be dissected and transplanted into adult animals. MGE-derived interneurons have high capacity of migration and autonomous integration. Also, these inhibitory neurons show a possibility of connecting and influence on a large number of excitatory cells and, therefore, they could improve memory and learning [41].

It appears that future studies and clinical trials in AD can go in different directions - stimulation of neurogenesis in the SVZ and hippocampus, but also in parts of the brain where it does not occur spontaneously, but where there are stem cells that can be induced to further differentiation; use of a growth factor that has neuroprotective potential of using the genetically modified stem cells. Due to the diffusion process and the diversity of damaged neurons local or systemic application of stem cells is the most therapeutic challenge.

\section{FUTURE PERSPECTIVES AND CHALLENGES}

The field of stem cell research in the area of neurodegenerative disorders is highly promising and still in its infancy. Neurodegenerative diseases affect human health due to their devastating nature, cost, and lack of effective therapies. Although stem cells offer a great promise of treating these ailments, there are still several issues needed to be solved prior to the translation of stem cells into clinical setting. Success of stem cell therapy depends on several critical issues, including route and accuracy of cell transplantation, long-term functionality of engrafted cells, and, most importantly, how cells interact with the host microenvironment. Currently there are several options for stimulating neurogenesis in therapy for neurodegenerative diseases and injuries, but none of it actually gave a long-term effect. Further studies examining the effectiveness of stem cells overexpressing various growth factors to reduce degeneration neurons and improve clinical outcomes will help to maximize the positive effects of cell therapy. Furthermore, the affinity for stem cells, especially MSCs, to migrate to the brain make them attractive for gene and drug delivery [56]. In clinics, although the use of stem cell therapy for neurodegenerative diseases has gained considerable momentum in the recent past, there are still numerous hurdles that must be overcome. It is extremely important that these stem cell-based therapies must pass vigorous safety and quality control testing. To date, most countries do not have established standard protocols for cell expansion and storage, handling and shipping of stem cells, to check quality of cells at the time of administration, and evaluate long-term safety. It is necessary to introduce aguidelines for more rigorous research practices, encourage more scientific clarity, and create stringent scientific standards that could guide the commercial development of stem cell-based therapies in the future. Altogether, while number of questions for stem cell application remain unanswered, the concerted efforts on stem cell research have already made a great progress toward cell replacement therapy in order to assure the best safety for patients. 


\section{CONCLUSION}

The development of neurological disease therapy with stem cells requires a detailed knowledge of the pathogenesis of these diseases, as well as which cell types are affected. In the treatment, depending on the disorder, a variety of cell types and neuroprotective molecules will be required. In some disorders, the therapeutic gain is likely to be achieved by transplanting the cells generated from stem cells in vitro, while in some other disorders therapeutic benefit may be obtained by stimulation of endogenous stem cells of CNS.

\section{REFERENCES}

1. Kolios G, Moodley Y. Introduction to stem cells and regenerative medicine. Respiration. 2013; 85(1):3-10.

2. Nurković J, Dolićanin Z, Tutić I, Hajrović Š, Mustafić F, Todorović V, Kovačević-Filipović M. Mezenhimalne matične ćelije iz masnog tkiva - izolacija, kultivacija i ciljana diferencijacija. Praxis Medica 2013; 42(3):45-50.

3. Nurković J, Lužajić T, Francuski J, Dolićanin Z, Radovanović A, Todorović V, Kovačević-Filipović M. Potencijal za diferencijaciju mezenhimalnih matičnih ćelija iz masnog tkiva čoveka. 5. Kongres medicine sporta i sportskih nauka sa mađunarodnim učešćem Beograd, 6-7. decembar 2012; Knjiga apstrakata, str. 10-11.

4. Volarevic V, Bojic S, Nurkovic J, Volarevic A, Ljujic B, Arsenijevic N, Lako M, Stojkovic M. Stem Cells as New Agents for the Treatment of Infertility: Current and Future Perspectives and Challenges. BioMed Res Int. 2014; 2014:507234.

5. Volarevic V, Nurkovic J, Arsenijevic N, Stojkovic M. Concise Review: Therapeutic potential of mesenchymal stem cells for the treatment of acute liver failure and cirrhosis. Stem Cells. 2014; 32(11): 2818-2823.

6. De Miguel MP, Fuentes-Julian S, Alcaina Y: Pluripotent stem cells: origin, maintenance and induction. Stem Cell Rev 2010; 6:633-649.

7. Evans MJ, Kaufman MH: Establishment in culture of pluripotential cells from mouse embryos. Nature 1981; 292:154-156.

8. Takahashi K, Yamanaka S: Induction of pluripotent stem cells from mouse embryonic and adult fibroblast cultures by defined factors. Cell 2006; 126:663-676.

9. Ishii T, Eto K. Fetal stem cell transplantation: Past, present, and future. World J Stem Cells. 2014; 6(4):404-420.

10. Augello A, Kurth TB, De BC: Mesenchymal stem cells: a perspective from in vitro cultures to in vivo migration and niches. Eur Cell Mater 2010; 20:121-133.

11. Barzilay R, Melamed E, Offen D: Introducing transcription factors to multipotent mesenchymal stem cells: making transdifferentiation possible. Stem Cells 2009; 27:2509-2515.

12. Nurkovic J, Mustafic F, Vucelj S, Mahmutovic E, Nurkovic S, Dolicanin Z. Mesenchymal stem cells from dental pulp. EMBO Conference Stem Cells in Cancer and Regenerative Medicine, Heidelberg - Germany, Oct 9-12, 2014. P131, p157.

13. Nurković J, Dolićanin Z. Induced differentiation of adipose-derived mesenchymal stem cells. 1st Annual Conference 2013 of the German Stem Cell Network (GSCN), Berlin - Germany, November 11-13, 2013. Abstracts No P091, p172.

14. Martínez-Morales PL, Revilla A, Ocana I, Gonzalez C, Sainz P, McGuire D, Liste I.. Progress in stem cell therapy for major human neurological disorders. Stem Cell Rev 2013; 9: 685-699.

15. Maldonado-Soto AR, Oakley DH, Wichterle H, Stein J, Doetsch FK, Henderson CE. Stem cells in the nervous system. Am J Phys Med Rehabil. 2014; 93(11 Suppl 3):S132-144.

16. Johansson PA, Cappello S, Gotz M. Stem cells niches during development-lessons from the cerebral cortex. Curr. Opin. Neurobiol. 2010; 20:400-407.

17. Rakić P. Limits of neurogenesis in primates. Science 1985; 227(4690): 1054-1056.

18. Johansson CB, Svensson M, Wallstedt L, Janson AM, Frisén J. Neuralstem cells in the adult human brain. Exp Cell Res 1999;253(2): 733-736.

19. Obradovic D, Balint B, Dincic E, Raicevic R, Obradovic $S$, Toncev $G$, Kostic V. Primenamatičnihćelija u lečenjuneurološkihoboljenja - da li je budućnostvećstigla? Vojnosanit Pregl 2008; 65(6): 473-480.

20. Ming GL, Song H. Adult neurogenesis in the mammalian centralnervous system. Annu Rev Neurosci 2005; 28: 223-250.

21. Gage FH. Mammalian neural stem cells. Science2000;287(5457): 1433-1438.

22. Robins SC, Stewart I, MCNay DE, Taylor V, Giachino C, Goetz M, Ninkovic J, Briancon N, Maratos-Flier E, Flier JS, Kokoeva MV, Placzek M. a-Tanycytes of the adult hypothalamic third ventricle include distinct populations of FGF-responsive neural progenitors. Nat. Commun. 2013; 4:2049.

23. Lin R, Cai J, Nathan C, Wei X, Schleidt S, Rosenwasser R, lacovitti L. Neurogenesis is enhanced by stroke in multiple new stem cell niches along the ventricular system at sites of high BBB permeability. Neurobiol. Dis. 2015; 74:229-239.

24. Koutmani $\mathrm{Y}$, Karalis KP. Neural stem cells respond to stress hormones: distinguishing beneficial from detrimental stress. Frontiers in Physiology. 2015; 6:77.

25. Temple S. The development of neural stem cells. Nature 2001;414(6859): 112-117. 
26. Tong $\mathrm{LM}$, Fong $\mathrm{H}$, Huang $\mathrm{Y}$. Stem cell therapy for Alzheimer's disease and related disorders: current status and future perspectives. Exp Mol Med. 2015; 47:e151.

27. Adami R, Scesa G, Bottai D. Stem cell transplantation in neurological diseases: improving effectiveness in animal models. Front Cell Dev Biol. 2014; 2:17.

28. Ortiz-Gonzalez XR, Keene CD, Verfaillie CM, Low WC. Neuralinduction of adult bone marrow and umbilical cord stem cells. CurrNeurovasc Res 2004; 1(3): 207-213.

29. Morís-De la Tassa G, Arias-Rodríguez M. Treatment of motor symptoms in Parkinson's disease. Rev Neurol. 2009; 48 Suppl 1:S2731.

30. Hauser RA. Early pharmacologic treatment in Parkinson's disease. Am J Manag Care. 2010; 16 Suppl Implications: S100-107.

31. Olanow CW, Rascol O, Hauser R, Feigin PD, Jankovic J, Lang A, Langston W, Melamed E, Poewe W, Stocchi F, Tolosa E. A double-blind, delayed-start trial of rasagiline in Parkinson's disease. N Engl J Med. 2009; 361:1268-1278.

32. Lindvall O, Kokaia Z. Stem cells for the treatment of neurologicaldisorders. Nature 2006; 441 (7097): 1094-1096.

33. Lindvall O, Rehncrona S, Brundin P, Gustavii B, Astedt B, WidnerH, Lindholm T, Björklund A, Leenders KL, Rothwell JC, Frackowiak R, Marsden D, Johnels B, Steg G, Freedman R, Hoffer BJ, Seiger A, Bygdeman M, Strömberg I, Olson L. Human fetal dopamine neurons grafted into thestriatum in two patients with severe Parkinson's disease. Adetailed account of methodology and a 6-month follow-up.Arch Neurol 1989; 46(6): 615-631.

34. Kordower JH, Freeman TB, Snow BJ, Vingerhoets FJ, Mufson EJ,Sanberg PR, Hauser RA, Smith DA, Nauert GM, Perl DP, Olanow CW. Neuropathological evidence of graft survivaland striatal reinnervation after the transplantation of fetal mesencephalictissue in a patient with Parkinson's disease. N EnglJ Med 1995; 332(17): 1118-1124.

35. Piccini P, Brooks DJ, Björklund A, Gunn RN, Grasby PM, RimoldiO, Brundin P, Hagell P, Rehncrona S, Widner H, Lindvall O. Dopamine release from nigral transplants visualized invivo in a Parkinson's patient. Nat Neurosci 1999; 2(12):1137-1140.

36. Olanow CW, Goetz CG, Kordower JH, Stoessl AJ, Sossi V, BrinMF, Shannon KM, Nauert GM, Perl DP, Godbold J, Freeman TB. A double-blind controlled trial of bilateral fetal nigraltransplantation in Parkinson's disease. Ann Neurol 2003;54(3): 403-414.

37. Piccini P, Pavese N, Hagell P, Reimer J, Björklund A, Oertel WH, Quinn NP, Brooks DJ, Lindvall O. Factors affecting the clinical outcome after neural transplantationin Parkinson's disease. Brain 2005; 128(Pt 12):2977-2986.

38. Gill SS, Patel NK, Hotton GR, O'Sullivan K, McCarter R, BunnageM, Brooks DJ, Svendsen CN, Heywood P. Direct brain infusion of glial cell line-derived neurotrophicfactor in Parkinson disease. Nat Med 2003; 9(5):589-595.

39. Huang Y, Mucke L. Alzheimer mechanisms and therapeutic strategies. Cell 2012; 148: 1204-1222.

40. Yu DX, Marchetto MC, Gage FH. Therapeutic translation of iPSCs for treating neurological disease. Cell Stem Cell 2013; 12: 678688.

41. Tong LM, Fong H, Huang Y. Stem cell therapy for Alzheimer's disease and related disorders: current status and future perspectives. Experimental \& Molecular Medicine. 2015; 47(3):e151.

42. Blurton-Jones M, Kitazawa M, Martinez-Coria H, Castello NA, Müller FJ, Loring JF, Yamasaki TR, Poon WW, Green KN, LaFerla FM. Neural stem cells improve cognition via BDNF in a transgenic model of Alzheimer disease. Proc Natl AcadSci USA. 2009; 106:13594-13599.

43. Park D, Joo SS, Kim TK, Lee SH, Kang H, Lee HJ, Lim I, Matsuo A, Tooyama I, Kim YB, Kim SU. Human neural stem cells overexpressing choline acetyltransferase restore cognitive function of kainic acid-induced learning and memory deficit animals. Cell Transplant. 2012; 21:365-371.

44. Yamasaki TR, Blurton-Jones M, Morrissette DA, Kitazawa M, Oddo S, LaFerla FM. Neural stem cells improve memory in an inducible mouse model of neuronal loss. J Neurosci 2007; 27: 11925-11933.

45. Suksuphew $S$, Noisa P. Neural stem cells could serve as a therapeutic material for age-related neurodegenerative diseases. World J Stem Cells. 2015; 7(2):502-511.

46. Elder GA, De Gasperi R, Gama Sosa MA. Research update: neurogenesis in adult brain and neuropsychiatric disorders. Mt Sinai J Med 2006; 73(7): 931-940.

47. Hodges H, Veizovic T, Bray N, French SJ, Rashid TP, Chadwick A, Patel S, Gray JA. Conditionally immortal neuroepithelial stem cell grafts reverse age-associated memory impairments in rats. Neuroscience 2000; 101(4): 945-955.

48. Malberg JE. Implications of adult hippocampal neurogenesis in antidepressant action. J Psychiatry Neurosci 2004; 29(3): 196-205.

49. Vučelj S, Zećović E, Nurković J. Mogućnostimagnetnerezonance u procenivolumenahipokampalneformacije. IX/XV kongresneurologaSrbijesameđunarodnimučešćem, Beograd; 14-16. novembar 2013; P52, p144.

50. Shin JY, Park HJ, Kim HN, Oh SH, Bae JS, Ha HJ, Lee PH. Mesenchymal stem cells enhance autophagy and increase B-amyloid clearance in Alzheimer disease models. Autophagy. 2014; 10:32-44.

51. Park D, Yang G, Bae DK, Lee SH, Yang YH, Kyung J, Kim D, Choi EK, Choi KC, Kim SU, et al. Human adipose tissue-derived mesenchymal stem cells improve cognitive function and physical activity in ageing mice. J Neurosci Res. 2013; 91:660-670.

52. Maler JM, Spitzer P, Lewczuk $P$, Kornhuber J, Herrmann M, Wiltfang J. Decreased circulating CD34+ stem cells in early Alzheimer's disease: Evidence for a deficient hematopoietic brain support? Mol Psychiatry 2006; 11(12): 1113-1115. 
53. Cogle CR, Yachnis AT, Laywell ED, Zander DS, Wingard JR, Steindler DA, Scott EW. Bone marrow transdifferentiation in brain after transplantation: a retrospective study. Lancet 2004; 363(9419): 1432-1437.

54. Fischer W, Wictorin K, Björklund A, Williams LR, Varon S, Gage FH. Amelioration of cholinergic neuron atrophy and spatial memory impairment in aged rats by nerve growth factor. Nature 1987; 329(6134): 65-68.

55. Tuszynski MH, Thal L, Pay M, Salmon DP, U HS, Bakay R, Patel P, Blesch A, Vahlsing HL, Ho G, Tong G, Potkin SG, Fallon J, Hansen L, Mufson EJ, Kordower JH, Gall C, Conner J. A phase 1 clinical trial of nerve growth factor gene therapy for Alzheimer disease. Nat Med 2005; 11(5): 551-555.

56. Aleynik A, Gernavage KM, Mourad YS, Sherman LS, Liu K, Gubenko YA, Rameshwar P. Stem cell delivery of therapies for brain disorders. Clinical and Translational Medicine. 2014; 3:24.

\section{SRPSKI}

\section{MATIČNE ĆELIJE U TERAPIJI NEURODEGENERATIVNIH BOLESTI VEZANIH ZA STARENJE}

Nurkovic J. ${ }^{1}$, Bisevac B. ${ }^{2}$, Mustafic F. ${ }^{3}$, Hajrovic S. ${ }^{4}$, Regic E. ${ }^{4}$, Nurkovic S. ${ }^{5}$, Kurtagic I. ${ }^{5}$, Dolicanin Z. ${ }^{1}$

${ }_{1}^{1}$ Departman za biomedicinske nauke, Državni univerzitet u Novom Pazaru, Srbija

${ }^{2}$ Medicinski fakultet u Prištini, sa privremenim sedištem u Kosovskoj Mitrovici, Univerzitet u Prištini, Srbija

${ }^{3}$ Medicinska škola Novi Pazar, Srbija

${ }^{4}$ Opšta bolnica Novi Pazar, Srbija

${ }^{5}$ Medicinski fakultet, Univerzitet u Beogradu, Srbija

\section{SAŽETAK}

Verovanje u nemogućnost neurogeneze, tj. nemogućnost stvaranja novih neurona posle rođenja i ranog postnatalnog perioda, odbačeno je sredinom devedesetih godina prošlog veka, kada je dokazana neurogeneza u određenim područjima CNS-a odraslih sisara, uključujući i čoveka. Transplantacija matičnih ćelija ili njihovih derivate u odgovarajuća tkiva ili organe smatra se jednim od lekova budućnosti za mnoge, za sada, neizlečive bolesti. U ovom preglednom radu, sumirali smo trenutno znanje, buduće perspektive $i$ izazove u primeni matičnih ćelija za lečenje Parkinsonove I Alchajmerove bolesti, kao najčešćih neurodegenerativnih bolesti vezanih za starenje.

Ključne reči: matične ćelije, Parkinsonova bolest, Alchajmerova bolest 